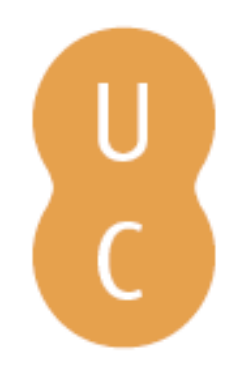

\title{
pommalina
}

\section{Murder after torture by side-arm: a case report}

Autor(es): $\quad$ Moriani, S.; Stornelli, G.; Siboldi, D.

Publicado por: Imprensa da Universidade de Coimbra

URL

persistente:

URI:http://hdl.handle.net/10316.2/31739

DOI:

DOI:http://dx.doi.org/10.14195/978-989-26-0173-1_67

Accessed : $\quad$ 26-Apr-2023 09:04:14

A navegação consulta e descarregamento dos títulos inseridos nas Bibliotecas Digitais UC Digitalis, UC Pombalina e UC Impactum, pressupõem a aceitação plena e sem reservas dos Termos e Condições de Uso destas Bibliotecas Digitais, disponíveis em https://digitalis.uc.pt/pt-pt/termos.

Conforme exposto nos referidos Termos e Condições de Uso, o descarregamento de títulos de acesso restrito requer uma licença válida de autorização devendo o utilizador aceder ao(s) documento(s) a partir de um endereço de IP da instituição detentora da supramencionada licença.

Ao utilizador é apenas permitido o descarregamento para uso pessoal, pelo que o emprego do(s) título(s) descarregado(s) para outro fim, designadamente comercial, carece de autorização do respetivo autor ou editor da obra.

Na medida em que todas as obras da UC Digitalis se encontram protegidas pelo Código do Direito de Autor e Direitos Conexos e demais legislação aplicável, toda a cópia, parcial ou total, deste documento, nos casos em que é legalmente admitida, deverá conter ou fazer-se acompanhar por este aviso. 


\section{Duarte Nuno Vieira Anthony Busuttil \\ Denis Cusack • Philip Beth}
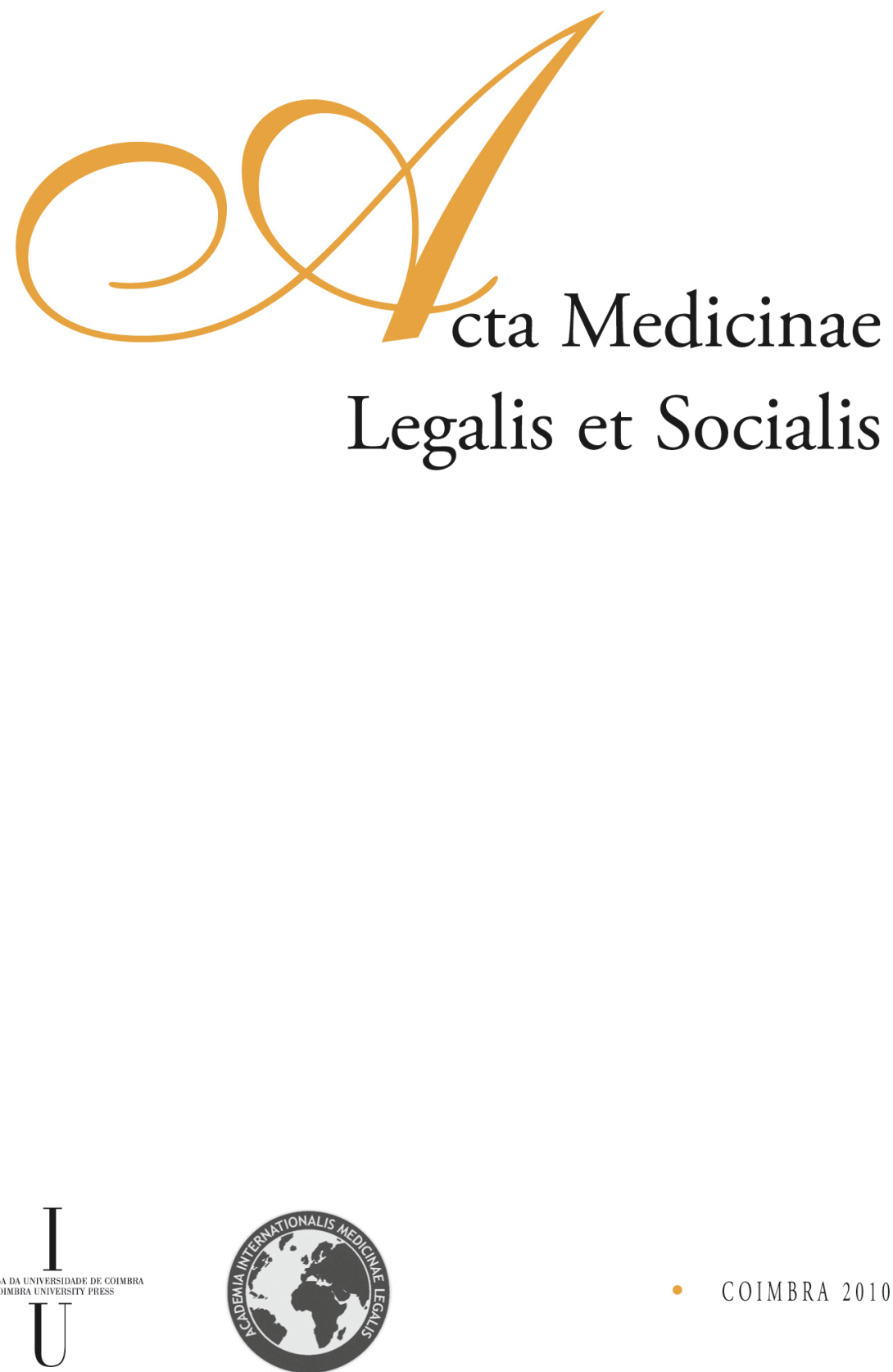


\title{
MURDER AFTER TORTURE BY SIDE-ARM: A CASE REPORT
}

\begin{abstract}
The authors present a case of a middle age man, who was found dead in his house. The examination of the crime scene and the forensic autopsy revealed several external injuries caused by a side-arm and a blunt instrument with different modalities. Autopsy revealed several external injuries due to a side-arm. The main wounds were superficial, mainly grouped in two different sites of the body: abdominal region and left leg. The fatal wound has caught up the heart through the thorax. A blunt injury was also found on the head. All the lesions had haemorrhagic infiltration; histology confirmed the vitality of all injuries. The interpretation of the medico-legal findings led to the hypothesis that the superficial wounds were inflicted to cause pain, while the only one, affecting the heart, was the final one. This hypothesis was confirmed by the reconstruction of the events in Court, where the suspects were sentenced for life imprisonment for inflicting lesions in order to gain information from the victim, and for murdering.
\end{abstract}

\section{Introduction}

The crime scene revealed the presence of a dead middle-aged man in the bathroom of his home. The human body was lying on the floor in supine position with his crura flexed on the thighs and his upper body - shoulders and head - lying on the wall; the lower extremity binding together by a plastic string (Fig. 1).

The inspection of the places showed the presence of a large pool below the body, in addition to several areas of bloodstain patterns located on the wash-basin, on the tiled wall above the head and on the tiles of the floor; there were also bloodspatters on the walls of the adjacent passage.

\section{Materials and methods}

We performed a medico-legal autopsy followed by histological examination of skin samples of regions interested by lesions. Toxicological analyses of blood, urine, gastric content, and bile samples were also conducted. 


\section{Results}

The detected thanatological phenomena were hypostasis, located to the back and to the lower limbs, difficult to discern, blanched by compression, and rigor mortis fully established, absence of decomposition changes.

The external examination found numerous wounds by side-arm:

A) three cutaneous cuts, with clean non-abraded edges, on the face: one linear, at the right eyebrow, over the supraorbital ridge, with oblique direction from top to bottom and from left to right; one on the right ear, semicircular shape, with lower concavity; one on the upper left lip, near an ecchymotic area of the buccal side (Fig. 2).

B) five to the chest: one at the left shoulder, superficial; one in the middle of the breadbone, linear, superficial; one in precordium, near to the left nipple, lozenged shape, with dull upper corner and lower acute, deep, and two on the left side, respectively 14 and $26 \mathrm{~cm}$ below the ipsilateral axilla, both lozenged shape, with acute angles above and below dull (Fig. 3, Fig. 4).

C) fifteen to the abdomen, below the left costal arch, lozenged shape, confined in an oval area, wide $18 \times 6 \mathrm{~cm}$, with obtuse angles higher and lower acute, deep (Fig. 5).

D) six cutaneous cuts, confined on the lateral surface of the left thigh, $14 \mathrm{~cm}$ long, parallel each other, of which the central penetrates soft tissue underneath (Fig. 6, Fig. 7).

E) two defense wounds of both hands (palm of the right hand and first finger of the left hand) (Fig. 8, Fig. 9).

At the occipital and parietal region, near the vertex (Fig. 10), there was an undermined laceration, $8 \mathrm{~cm}$ long, produced by a bottle, inside an oval area of abrasion, wide $\mathrm{cm} 7 \times 5$ and, at the back of the neck (Fig. 11), there was an abrasion, with slight indentation of the skin between parallel top and bottom line of demarcation, 14.6 $\mathrm{cm}$ long, thickness of $0.8 \mathrm{~cm}$ on the left and $0.2 \mathrm{~cm}$ on the right (Fig. 12, Fig. 13).

The autopsy revealed that the cutaneous sharp force injuries, penetrating into cavities that drew vital organs, were the following: the precordial one, interesting pericardium and anterior surface of the left ventricle, the upper left latus penetrating into the chest cavity and cutting the lower edge of the upper lobe of the left lung and eight stabs penetrated in the abdominal cavity, three of which pierced the stomach full-thickness and one draws the left lobe of the liver.

The toxicological investigations, performed on blood, urine, bile and gastric content were negative. Histology confirmed the vitality of all injuries.

\section{Discussion}

The United Nations (UN) Convention defines torture as: "any act by which severe pain or suffering, whether physical or mental, is intentionally inflicted on a person for such purposes as obtaining from him or a third person information or a confession, punishing him for an act he or a third person has committed or is suspected of having committed, or intimidating or coercing him or a third person, or for any reason based on discrimination of any kind, when such pain or suffering is inflicted by or at the instigation of or with the consent or acquiescence of a public official or other person 
acting in an official capacity. It does not include pain or suffering arising only from, inherent in or incidental to lawful sanctions". The UN Convention against torture, adopted in 1984, is one of the least ratified major human rights treaties.

There is clear evidence for widespread use of torture among political prisoners throughout the world. Medical personnel frequently become involved, sometimes directly, often peripherally, for example, examining or treating victims.

In our case, the crime scene showed the immobilization of lower extremities binded together by a plastic string and the autopsy revealed different modality of injuries: stab and cut wounds by side-arm, laceration on the head by blunt trauma, abrasion on the neck by a tentative of strangulation. All cuts and stabs wounds in the skin were produced by a single blade side-arm with typical mechanisms of sharp force injury.

The multiple clustered stab and cut wounds were confined to three areas of the body (root of the left thigh, abdominal area, left lumbar side) and were characterized by the uniformity of production, implemented with low power, by the spatial concentration and by the homogenous depth. All the lesions had haemorrhagic infiltration of the margins; therefore histology examination confirmed the vitality of all injuries.

Most of the wounds was superficial, while the only one, affecting the hearth, was the fatal one. In fact, the cause of death can be ascribed to the stab wound to the heart.

For what concerns the determination of the time of death, the interpretation of the crime scene and autopsy findings have helped us in identifying a postmortem interval of about 12-16 hours.

\section{Conclusion}

In many instances, the autopsy appearances of lethal torture are not different from those by any other homicide and the confirmation must depend upon circumstantial and other corroborative evidence.

In our case, the crime scene examination, the immobilization of lower extremities, the mechanism of injury and the characteristics of the lesions led us to suppose that the purpose of the murderer(s) was to injure but not to cause death immediately and so the superficial wounds were inflicted to cause pain, while the only one, affecting the hearth, was aimed to be fatal.

Our hypothesis of reconstruction of the homicide - immobilization and torture of the victim - was then confirmed by the Court, where the suspects were recognized to be guilty and sentenced for life imprisonment for inflicting lesions in order to obtain information from the victim and then for murdering.

\section{References}

Convention against Torture and Other Cruel, Inhuman or Degrading Treatment or Punishment, United Nations, 10 December 1984.

DI MAIO V.J., DI MAIO D., "Forensic Pathology", second edition, Boca Raton, Florida, USA; CRC Press LLC, 2001.

Knight B., "Forensic Pathology", second edition, London, UK, Arnold, 1996.

Spitz and Fisher's, "Medicolegal Investigation of Death. Guidelines for the Application of Pathology to Crime Investigation"; Springfield, Illinois, USA; Charles C Thomas Publisher, LTD; 2006. 


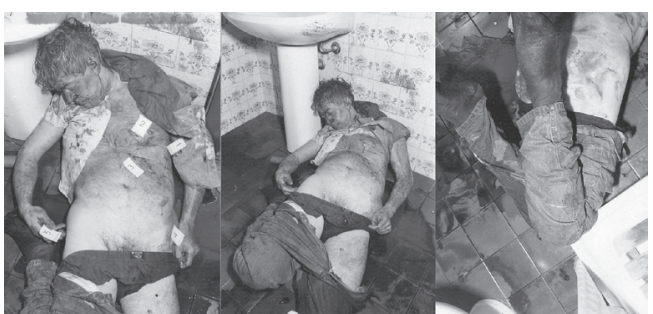

Figure - 1

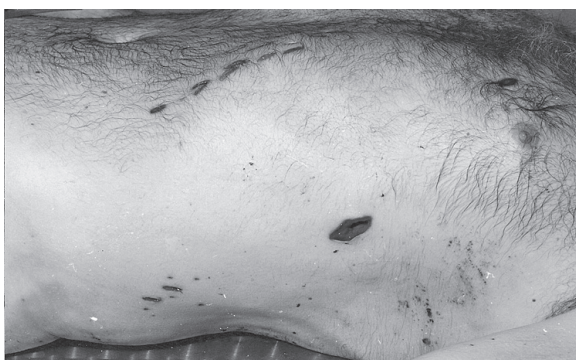

Figure - 3

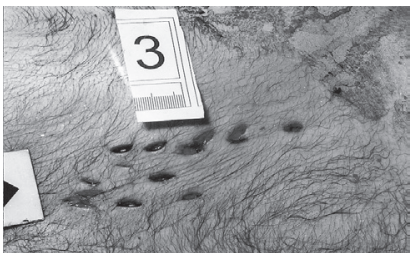

Figure - 5

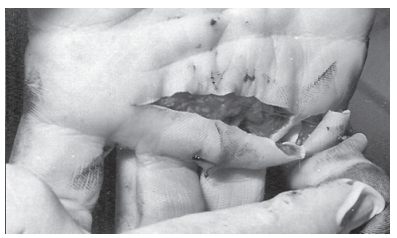

Figure -8

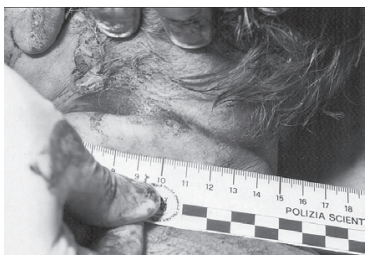

Figure - 11

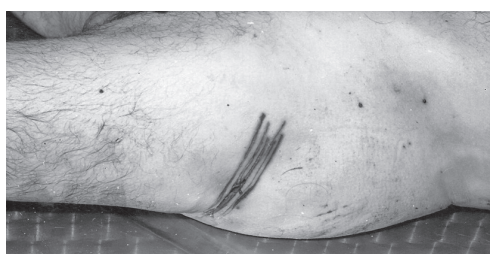

Figure - 6

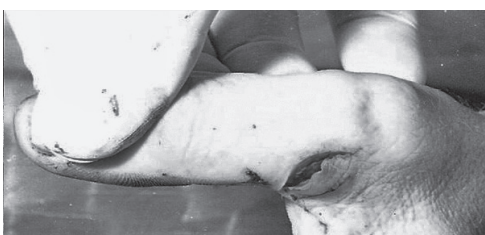

Figure - 9

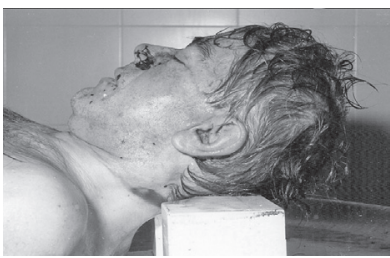

Figure - 12

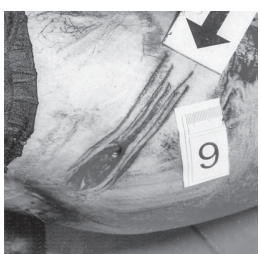

Figure - 7

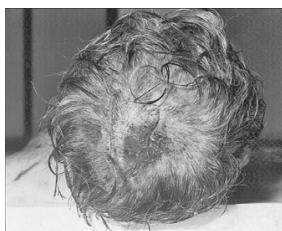

Figure - 10

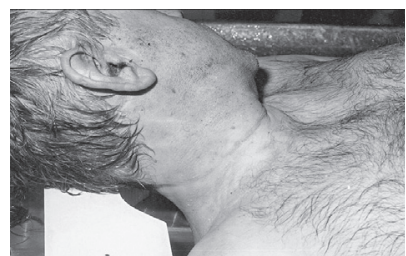

Figure - 13 